\title{
DAVID ROBERTS EN CÓRDOBA. VISTAS DE PAISAJE Y ARQUITECTURA HACIA 1833
}

\author{
Antonio Gámiz Gordo y Antonio Jesús García Ortega \\ Universidad de Sevilla
}

Las vistas realizadas en Córdoba por David Roberts en 1833, reelaboradas como litografías, grabados y óleos, han gozado de gran éxito comercial y difusión internacional por su temática e indudable interés artístico. Esta investigación profundiza en su valor documental como registros gráficos previos a la aparición de la fotografía, del paisaje y la arquitectura de una ciudad hoy considerada Patrimonio de la Humanidad.

Las imágenes presentadas se analizan por primera vez como conjunto, pues algunas son de difícil localización o están dispersas en museos de todo el mundo, y se contextualizan con datos sobre el pintor y su viaje por España, considerando una carta que éste escribió desde Córdoba. También se valora la fiabilidad documental de cada vista, a la vez que se detectan significativas transformaciones de los lugares representados.

Palabras clave: Roberts; Córdoba; Vistas; Paisaje; Arquitectura.

\section{DAVID ROBERTS IN CORDOBA. VIEWS OF LANDSCAPE AND ARCHITECTUREAROUND 1833}

David Roberts' views of Córdoba were carried out in 1833 and later redrafted as lithographs, engravings, and oils. These artworks enjoyed great commercial success and international diffusion due to their thematic and undoubted artistic value. The authors analyze their documentary value as a graphic record -prior to the advent of photography- of the urban landscape and architecture of Cordoba, a city now denominated a World Heritage Site.

These images are studied here for the first time as a group, since they are either virtually untraceable or dispersed in museums throughout the world. In addition, these views have been contextualized with information concerning the artist and his Spanish journey, including a letter that he wrote from Córdoba. The documentary reliability of every image is also assessed, while the significant transformations of the places represented are indicated.

Key words: Roberts; Cordoba; Views; Landscape; Architecture.

David Roberts recorrió España entre 1832 y 1833, realizando innumerables vistas de ciudades y monumentos, especialmente de Andalucía, que en gran parte fueron reelaboradas y publicadas tras su vuelta a Inglaterra. Sus dibujos, acuarelas y óleos gozaron de gran éxito comercial como litografías y grabados de forma que, en momentos previos a la aparición de la fotografía, el público culto de la 
Europa del siglo XIX pudo acceder a lugares poco conocidos hasta entonces, conformándose una imagen de nuestros territorios que ha marcado su personalidad hasta tiempos actuales ${ }^{1}$.

En enero de 1833, a su paso por Córdoba, Roberts realizó una nutrida serie de vistas, hoy dispersas o de difícil localización, abarcando distintas escalas, desde el paisaje urbano hasta interiores arquitectónicos. Por primera vez aquí se aborda su análisis conjunto, atendiendo a su emplazamiento y temática, considerando el contexto del pintor y su viaje por España. También se valora su fiabilidad documental, a la vez que se detectan transformaciones en los lugares dibujados.

Para su adecuada interpretación resulta crucial la comparación entre sus dibujos originales y sus más conocidas versiones publicadas como litografías (1837), grabados al acero y viñetas (1835-1838), o sus posteriores óleos. No debe olvidarse que dichas vistas fueron objeto de numerosas reediciones y plagios posteriores, que en muchos casos desvirtuaron su valor documental y pictórico. En este sentido, el presente estudio también pretende abrir una reflexión sobre las modificaciones que, a partir de los dibujos originales de Roberts, introdujeron grabadores, litógrafos o incluso el propio pintor.

Dicha cuestión ha motivado ciertas opiniones o tópicos que le atribuyen poca fiabilidad documental y que deben matizarse a la luz del presente análisis de las vistas cordobesas ${ }^{2}$. Además de atender a las diferencias entre los originales y sus reelaboraciones, a lo largo de esta investigación se han realizado comparaciones con imágenes de otros autores, planos de la época e incluso con el estado actual de los lugares representados. Todo ello se ha contextualizado con una síntesis de su viaje por España y con la carta que Roberts escribió desde Córdoba, cuyo original se ha localizado y consultado para el presente trabajo en la National Library of Scotland.

\section{El contexto del pintor y sus dibujos por España}

David Roberts (1796-1864) nació cerca de Edimburgo en el seno de una familia muy humilde, de padre zapatero remendón y madre lavandera. A los doce años entró como aprendiz en el taller de un pintor y decorador de mansiones escocesas. Tras siete años de arduo trabajo encontró empleo como pintor de escenografías en una compañía de teatro ambulante, lo que le permitió viajar, pintar escenas a gran escala y dibujar los sitios visitados. Según el propio autor, al dibujar la catedral de York descubriría su vocación como pintor viajero ${ }^{3}$.

Desde 1816, hasta cerca de 1830, Roberts se dedicó a la escenografía, trabajando en los teatros más importantes de Escocia e Inglaterra, resolviendo múltiples composiciones gráficas para las que se requería gran inventiva, inmediatez e intensidad expresiva, lo que le haría crecer como artista. Al gozar de una posición económica más cómoda pudo dedicarse a la pintura. Desde 1824 fue miembro de la recién creada Society of British Artists donde exhibió muchos cuadros ejecutados

\footnotetext{
${ }^{1}$ Al viaje de Roberts por España se dedica el libro de Giménez Cruz (2002), que reconstruye su itinerario sin estudiar sus vistas, usando las cerca de 60 cartas del pintor conservadas y en gran parte publicadas por su primer biógrafo, Ballantine (1866). Hay otros dos importantes libros sobre Roberts, la biografía de Sim (1984) y el catálogo de una exposición en Londres en donde Guiterman y Llewellyn (1986) trataron de compendiar la prolífica obra del pintor en sus viajes por Escocia, Inglaterra, Francia, Bélgica, Holanda, Alemania, España, India, Oriente Próximo e Italia. Además, un artículo de Gámiz Gordo (2010) reseña muchas de las incontables vistas originales que el pintor realizó en España, hoy dispersas en museos o colecciones particulares por todo el mundo.

2 Algunos autores han formulado juicios críticos sobre Roberts que deberían reconsiderarse, como Calvo Serraller (1995: 22-ss y 95-96) al comentar: “en estas representaciones predomina lo fantástico sobre lo real...". Asimismo Galera Andreu (1992: 134-137) dice sobre nuestro pintor: "la objetividad, el realismo o la exactitud, no son valores a tener muy en cuenta en esta forma de mirar y de reflejar el paisaje o decorado".

${ }^{3}$ Giménez Cruz, 2002: 21-ss.
} 
con motivo de sus viajes ${ }^{4}$. Desde entonces recibiría suculentos encargos e incluso años después presidiría la citada Sociedad de Artistas Británicos.

Hacia 1830 Roberts tenía cierta madurez profesional y suficientes recursos económicos para iniciar un viaje por España que poco antes habían emprendido amigos suyos, pintores o destacadas figuras del momento, como David Wilkie, John Frederick Lewis o Richard Ford. La oportunidad de contemplar obras de maestros como Velázquez, Murillo o Zurbarán ejercería un considerable atractivo sobre nuestro artista. Por entonces España estaba de moda y existía una notable demanda del público inglés por asuntos españoles, poco conocidos o considerados como exóticos. Ello haría pensar al pintor que los considerables esfuerzos y gastos de su viaje se verían recompensados al comercializar sus vistas españolas a su regreso, como de hecho ocurrió.

Muchos pormenores de su itinerario, marcado por calamitosas epidemias, se conocen por sus cartas y por un diario personal conocido como Record Book ${ }^{5}$. Roberts trataría en todo momento de aprovechar al máximo su viaje, sin dejar jamás a un lado su lápiz o pincel. Solía dibujar sobre cuadernos de bolsillo, de reducido tamaño (unos 10 por $17 \mathrm{~cm}$.) que luego le servían para componer escenas complejas y detalladas. Según Sim: "lo que maravilla de estos bocetos, la mayoría a lápiz o aguada en papel ligeramente coloreado, no es sólo la nitidez y delicadeza del trazo, sino también la sorprendente exactitud de los sutilmente esbozados detalles"6.

También debe subrayarse la gran capacidad de Roberts para acometer con rapidez y precisión dibujos fieles a la realidad. Según Ballantine, amigo personal de Roberts, éste "tenía la capacidad de fotografiar objetos con la vista, porque una y otra vez yo le he visto hacer bocetos de estructuras muy complejas o de panorámicas muy amplias, y le bastaba una ojeada rápida para captar la totalidad del conjunto, no necesitando nunca más volver a mirar en ese dirección hasta que había finalizado el boceto"'. La inmediatez exigida a nuestro pintor en su juventud al ejecutar decorados teatrales le dotaría de esa facilidad para memorizar y plasmar sus imágenes con precisión.

Para dar una idea aproximada de la prolífica producción gráfica de Roberts, que sólo en Andalucía se ha estimado en $250 \operatorname{vistas}^{8}$, y de sus intereses paisajísticos o monumentales, seguidamente se resume su itinerario por España, citando algunas de sus imágenes.

Roberts inició su periplo en octubre de 1832. Apenas existe información de sus primeras etapas de viaje. Se conocen tres grabados sobre el País Vasco. Roberts pasaría una noche en Vitoria y en su camino hacia Burgos tomó una vista de Miranda del Ebro y otra del desfiladero de Pancorbo. Estuvo una semana en Burgos, ciudad a la que dedicó cinco grabados, teniéndose noticia de acuarelas, alguna vista a lápiz y óleos posteriores sobre su Catedral ${ }^{9}$.

El 16 de diciembre de 1832 llegó a Madrid, donde pasó aquellas navidades. Allí disfrutaría de los grandes maestros españoles en el Museo del Prado y se encontraría con pintores de la época como Federico Madrazo o Vicente López. En una de sus cartas, nuestro pintor citaba de forma muy crítica la situación de la pintura de paisaje en España en aquel momento: "es una calumnia darle ese nombre" ${ }^{10}$. Se conocen algunos dibujos originales tomados en su estancia madrileña, que dieron lugar a seis grabados y dos litografías ${ }^{11}$.

\footnotetext{
${ }^{4}$ Quesada, 1996: 86-ss.

${ }^{5}$ Una copia de dicho diario o "Record book" se conserva en la Barbican Art Gallery.

${ }^{6}$ Sim, 1984: 68.

${ }^{7}$ Ballantine, 1866: 231.

${ }^{8}$ Quesada, 1996: 87.

9 Guiterman y Llewellyn, 1986: 48, 57, 107-108, cat. 81, 82, 83, 84.

${ }^{10}$ Giménez Cruz, 2002.

${ }^{11}$ Gámiz Gordo, 2010: 58-59.
}

Arch. esp. arte, LXXXVIII, 352, oCTUBRE-DICIEMBRE 2015, 367-386 ISSN: 0004-0428, eISSN: 1988-8511, doi: 10.3989/aearte.2015.23 
Roberts salió de Madrid el 9 de enero de 1833 y llegaría a Córdoba el 12 ó 13 de enero, donde permaneció unas tres semanas. En la carta que allí escribió decía: "mi porfolio va enriqueciéndose más y más, siendo los temas no sólo buenos, sino también originales, y lo único que me preocupa es si seré capaz de pintar la mitad de ellos. Suman aproximadamente un centenar, y todavía tengo previsto visitar seis ciudades, por lo que me temo que lo mejor está todavía por llegar". Sobre esta ciudad se han localizado unas catorce vistas originales, cinco litografías, cuatro grabados y tres viñetas.

Roberts prosiguió su camino y tomó vistas en Luque y Alcalá la Real llegando a Granada en febrero de 1833. Maravillado por la ciudad y por la Alhambra, en una carta a su hermana decía: "La arquitectura es tan elaborada y original que llevaría meses representarla con justicia"12. Roberts permaneció allí unas dos semanas, pero tuvo que salir precipitadamente cuando las autoridades militares le prohibieron seguir dibujando. Granada fue la ciudad española que acaparó mayor número de grabados, quince, más cinco litografías, viñetas y diversos originales.

Partiría hacia Málaga el 25 ó 26 de febrero. Debió pasar por Loja, ya que sobre esta ciudad y su Alcazaba existe un grabado y un original. Sobre Málaga hay dos grabados y una litografía, más una rara litografía dedicada al cementerio inglés y varios originales inéditos. En su camino hacia Gibraltar pasó por Ronda, que cuenta con dos grabados, y al menos una acuarela y un óleo. Otro grabado incluye el pueblo de Gaucín mirando hacia Gibraltar ${ }^{13}$.

Roberts llegaría a Gibraltar el 19 ó 20 de marzo. Le dedicó un grabado y una litografía al Peñón más un posterior óleo fechado en $1853^{14}$. En una de sus cartas escrita desde allí comentaba: "muchos de los dibujos son muy originales, y sin contar los pequeños cuadernos, tengo ya doscientos seis bocetos terminados, la mayor parte en color". Y en otra carta decía que el gobernador de Gibraltar insistía "en hacerse cargo de mis dibujos y de enviarlos directamente a Inglaterra, con el fin de evitar el riesgo de que tengan que pasar otra vez por España. Este amable ofrecimiento lo he aceptado gustosamente, ya que mis dibujos pasan ya de doscientos"15.

Cruzó el Estrecho para visitar Tánger, Tetuán y otras ciudades del norte de África. Y el 23 de abril prosiguió su rumbo hacia Cádiz, que dio lugar a un grabado de Tarifa y otro de Cádiz. Sobre Jerez hay tres grabados más dos litografías y se conocen diversos originales. A principios de mayo llegó a Sevilla, donde permaneció cinco meses. Allí mantuvo encuentros con jóvenes pintores y ejerció una notable influencia sobre el paisajista Jenaro Pérez Villaamil. A esta ciudad dedicaría variados dibujos previos a siete grabados, cuatro litografías y dos excepcionales óleos ${ }^{16}$. Sobre sus alrededores hay un grabado a Itálica, debiendo destacarse una vista del castillo de Alcalá de Guadaira, antecedente de un óleo con una bellísima puesta de sol, hoy en el Museo del Prado. Además realizó originales en Carmona que dieron lugar a un grabado y dos litografías ${ }^{17}$. Debido a una epidemia de cólera, Roberts tuvo que abandonar precipitadamente Sevilla y con grandes dificultades tomó allí un barco, llegando a su país en octubre de 1833.

En Inglaterra Roberts reelaboró abundantes vistas de los temas dibujados en España al menos durante cinco años. En su obra "Picturesque sketches in Spain. Taken during the years 1832-1833" (1837) se publicaron veintiséis litografías y cerca de setenta grabados al acero (más pequeñas viñetas) en cuatro tomos editados con el título "The tourist in Spain" (1835, 1836, 1837 y 1838) con los mejores litógrafos y grabadores del momento, incluyendo textos de T. Roscoe.

\footnotetext{
12 Giménez Cruz, 2002: 142-143.

${ }^{13}$ Gámiz Gordo, 2010: 61-62.

${ }^{14}$ Guiterman y Llewellyn, 1986: 109.

${ }^{15}$ Giménez Cruz, 2002: 56, 215 y 218.

${ }^{16}$ Gámiz Gordo, 2010: 62.

17 Gámiz Gordo, 2014.
} 
Dado que no pudo completar su viaje, para los tomos III y IV de esta publicación decidió usar bocetos de otros viajeros sobre lugares que no visitó. Existen serias dudas de que Roberts dibujase en Segovia, El Escorial y Toledo, ya que no se citan en el Record Book y en la carta escrita desde Córdoba Roberts expresaba su intención de visitarlas a su regreso, que finalmente hizo en barco. Las vistas sobre Salamanca, Plasencia, o Santiago de Compostela se basaron en dibujos de Richard Ford, y las de Valencia y Zaragoza en dibujos de otros autores ${ }^{18}$.

Roberts acometió muchas versiones o variantes a partir de sus bocetos de viaje. A menudo jugaba con los efectos de la composición, con los contrastes de luces (atardeceres, vistas nocturnas...) introduciendo personajes, reconstruyendo a veces arquitecturas perdidas, alterando escalas en ciertos lugares, incluso añadiendo elementos no recogidos en sus bocetos. Algunas de estas versiones se realizaron mucho tiempo después de su viaje, como un cuadro sobre Carmona que Roberts regaló a su dentista, fechado en $1853^{19}$. A pesar de ello, Roberts mantuvo las cuestiones esenciales de los temas representados, según vamos a ver en el caso de Córdoba.

\section{David Roberts en Córdoba}

Roberts llegaría a Córdoba, procedente de Madrid el 12 ó 13 de enero de 1833, permaneciendo en la ciudad unas tres semanas. A través de sus imágenes se deduce lo que más le pudo impresionar: la fachada de la ciudad al río y su zona monumental, donde se encuentran el Alcázar, el Puente Romano, los molinos y la Mezquita-Catedral, de cuyo interior realizó diversas vistas. Todo ello, con las montañas de Sierra Morena como fondo paisajístico, conformaba un enclave alabado en la carta que escribió desde Córdoba entre el 20 y el 30 de enero de 1833 a su amigo D. R. Hay ${ }^{20}$. Entre sus párrafos decía:

"Estoy como si viviera en un mundo nuevo. Aquí la primavera está en todo su esplendor, y el tiempo es tan agradable como el nuestro a final de Mayo. Ahora mismo, desde donde te estoy escribiendo, las rosas y los lirios junto a mi ventana están en flor; a mi alrededor, los jardines de naranjos rebosan de frutos. Una inmensa palmera yergue en el patio. Los setos alrededor están hechos con aloe y otras plantas características de este clima mediterráneo. Aquí apenas conocen el invierno; pero tú no debes suponer que todo esto es completamente como en un paraíso, porque tengo picaduras de mosquitos por todas partes, así que apenas puedo dormir por la noche. La situación de la ciudad es bella; se eleva junto al Guadalquivir, cuyas orillas están tapizadas de verdor, con las pintorescas montañas de Sierra Morena extendiéndose casi hasta las murallas; $y$ aunque la Córdoba actual es una de las más deterioradas y miserables ciudades de España, para el anticuario o el artista su riqueza no tiene límites. La maravilla de Córdoba es la Mezquita, tan sólo superada por La Meca. La superficie que ocupa no es inferior a 512 por 428 pies, dejando a un lado los claustros y el jardín. Se levanta sobre un lugar en el que existía un templo romano, con cuyas ruinas dicen que se construyó, aunque el hecho es que debió de erigirse sobre una serie de templos, ya que, estudiando el plano que he realizado, hay por lo menos 632 columnas de mármol pulido, eso sin contar las más pequeñas -todas son de estilo corintio- de diferentes formas y tamaños, y algunas

18 Gámiz Gordo, 2010: 64.

19 Guiterman y Llewellyn, 1986: 108

${ }^{20}$ Carta manuscrita por David Roberts en Córdoba, con 4 páginas. National Library of Scotland (MS 2531-2, fol. 53-54). El documento se había datado el 30 de enero de 1833, según fecha incluida al final del mismo, pero en su encabezamiento también figura el 20 de Enero de 1833, fecha en la que debió iniciarse su redacción. Aquí se recogen las partes más significativas del texto, tras consultar la versión en inglés que publicó Ballantine, 1866: 46-48, con una traducción propia.

Arch. esp. arte, LXXXVIII, 352, oCTUBRE-DICIEMBRE 2015, 367-386 ISSN: 0004-0428, eISSN: 1988-8511, doi: 10.3989/aearte.2015.23 
de ellas son verdaderamente de proporciones exquisitas. La ciudad, con anterioridad a los árabes, era célebre por ser la cuna de Séneca y Lucano, y es rica en los mejores restos de arquitectura. Puede decirse que no hay ni una casa, calle o callejuela en la que no haya un capitel corintio o friso en sus paredes. Todo portal o casa cuya esquina dé a una calle o pasadizo, es adornado con una columna de mármol, en la mayoría de los casos acanalada. Este lugar es un campo de búsqueda para los anticuarios".

Las primeras sensaciones de nuestro artista en Córdoba serían contradictorias, entre la satisfacción de su viaje y cierta nostalgia por sus amigos y familiares en Escocia. Pese a que disfrutaba con la vegetación, los colores del lugar o la calidez del clima, y que las frutas y vinos le parecían excelentes, no olvidaba un buen whisky escocés en compañía de un viejo amigo. Así, dando noticias de su buena salud y de su llegada a Andalucía, expresaba su intención de volver a Inglaterra a finales de abril o primeros de mayo, unas previsiones que no se cumplieron.

Como era de esperar Roberts quedó sorprendido por la magnífica Mezquita-Catedral, que describe con interés y admiración. Y pese a la imagen decadente de la ciudad ${ }^{21}$, se sentiría fascinado por un esplendoroso pasado que estimularía su imaginación. Su carta finalizaba diciendo: "Ahora me voy a fumar un cigarro, tumbarme en la cama, donde estoy seguro que estará Vd. tras leer con dificultad este interminable galimatías sobre romanos, godos, árabes y cristianos que, sin embargo, me ha valido para despejar la mente".

Las vistas de Roberts, junto a las de otros destacados personajes que dibujaron Córdoba en aquel tiempo, como Laborde (1812)22, Taylor (1832), Vivian (1838), Chapuy (1842-44) o Guesdon (h. 1853-55) constituyen un valioso testimonio gráfico del estado que entonces presentaba la ciudad y su Mezquita-Catedral, en vísperas de importantes reformas. Sólo décadas después la fisonomía urbana empezó a cambiar de forma irreversible con la llegada del ferrocarril en 1859, la demolición de gran parte de la muralla, torres y puertas, la apertura interior de rectos viarios, o la construcción del muro de defensa contra las crecidas del río.

Algunas de estas transformaciones pueden valorarse a través de los originales cordobeses de Roberts sobre paisaje urbano hasta ahora localizados: una acuarela del Alcázar, en el Dudley Museum; otra del Alcázar, base de un posterior grabado, en la Whitworth Art Gallery; dos dibujos de la Albolafía, uno en una colección particular granadina y otro subastado en Christie's; una acuarela y un óleo de la torre de la Calahorra, subastados en Christie's y en Sothebys; más dos variantes de la iglesia de San Nicolás, una acuarela en The Fitzwilliam Museum y un óleo en The Hepworth Wakefield. Sobre el pórtico de una anónima casa cordobesa, identificada en este artículo, se conoce un original, base de una litografía. Y otros originales se dedicaron al interior de la Mezquita-Catedral: dos acuarelas en colecciones privadas, otra subastada en Sothebys; un óleo en Leicester Galleries, y otro excepcional óleo en el Museo del Prado, según vamos a ver.

A partir de algunos de los citados originales y de otros desconocidos, se publicaron cuatro grabados (1836): la ciudad mirando hacia el Guadalquivir, el interior de la Mezquita, el Alcázar o Cárcel de la Inquisición, la torre de la iglesia de San Nicolás. Y cinco litografías (1837): una vista general del puente y el río con la Mezquita al fondo (lám. XXIV), un molino y el puente sobre el Guadalquivir (lám. XXII), una portada de acceso a la ciudad (lám. XII), el pórtico de un patio (lám. XXI) y la capilla de la Mezquita (lám. XIII). Más tarde grabó otra vista general con el puente

${ }^{21}$ Esta impresión de decadencia urbana es coincidente con otras descripciones de viajeros, como Henry Inglis, cuyo libro pudo conocer Roberts, pues se expresaba en términos parecidos. Decía Inglis, 1931, vol. II: 38: "su situación es la única gloria que le queda a Córdoba: la ciencia ha encontrado otros refugios y la riqueza otros caminos, pues Córdoba es hoy día una de las ciudades españolas más decrépitas, más deshabitadas y más ruinosas".

${ }^{22}$ Gámiz Gordo y García Ortega, 2012. 
y la Mezquita. Además hay tres viñetas (1835) de menor valor documental, sobre la puerta del Puente y sobre el interior de la Mezquita (Capilla Real y Mihrab) ${ }^{23}$.

\section{Recorrido por las vistas del paisaje urbano de Córdoba.}

Una de las más bellas imágenes paisajísticas de Córdoba es la litografía de Roberts titulada "Great Mosque and Palace of the Archbishop, Cordova" (T. S. Boys, lit.; pl. XXIV, 1837) (fig. 1). En ella se representa la zona monumental de la ciudad, contemplada desde la orilla opuesta del Guadalquivir, un punto de vista habitual entre artistas que dibujaron Córdoba en la primera mitad del siglo XIX, como Laborde, Prangey, Vivian, Chapuy y otros. La gran Mezquita, con la Catedral cristiana emergiendo desde su interior, protagoniza el encuadre. En segundo plano aparece su torre, que envuelve el alminar que mandó construir Abderramán III, transformado en los siglos XVIXVII con un lenguaje clásico y con la adición de un cuerpo de campanas. El puente se dibuja con esmero, precisando cada arco con su distinto perfil, consecuencia de sus numerosas reconstrucciones, y se detallan las hornacinas existentes en su zona central. La composición tiene como fondo las montañas de Sierra Morena y se completa con elementos incluidos en otras vistas suyas, plasmados con gran fidelidad: el Triunfo de San Rafael, la Puerta del Puente, los molinos del río y sus azudas $^{24}$, el Palacio Episcopal, etc. A la izquierda aparece una parte del Alcázar y varias palmeras, propias del clima templado cordobés que tanto agradó a Roberts, según su carta ${ }^{25}$. El encuadre de Roberts no incluye la torre defensiva del extremo sur del puente, llamada de la Calahorra, a la que dedicó una acuarela, base de un posterior óle ${ }^{26}$, con el punto de vista situado en el cercano molino fluvial de San Antonio.

Una vista tomada desde la misma orilla sur del río, al otro lado del puente se titula "The Great Mosque \& the Alcazar, or Dungeon of the Inquisition, Cordova, on the Guadalquiver" (engraved by T. Higham) (fig. 2) y no fue publicada en 1836 con los otros grabados cordobeses de Roberts, sino en 1845. Su título no habla de Catedral cristiana, sino de Mezquita, resaltando su pasado islámico. Por error se llama "Alcázar o Cárcel de la Inquisición” al Palacio Episcopal, situado a la izquierda de la Mezquita-Catedral, y dibujado por Roberts en otras de sus vistas. El punto de vista es cercano al anterior pero esta imagen tiene distinto carácter, resulta menos espontánea, quizás porque se grabó años después o en base a un dibujo menos elaborado. El protagonismo de la Mezquita-Catedral es aún mayor, en detrimento de los monumentos de su entorno, estirándose verticalmente; también la torre se desplaza intencionadamente para no quedar oculta tras la Mezquita-Catedral y se sobredimensiona su cuerpo de campanas, acortándose su base o fuste. Resulta interesante la representación del borde urbano, previa a la construcción del muro de defensa junto al río: la ciudad se relaciona amablemente con dicho espacio, las casas no siguen una alineación recta y es un lugar lleno de actividad, con escenas de pesca, personajes que charlan, gentes que transitan o se asoman al puente.

${ }^{23}$ El análisis ofrecido a continuación se apoya en el estudio del conjunto de imágenes cordobesas localizadas, reproduciéndose aquí las más significativas. Del resto se aportan referencias para facilitar su consulta.

${ }^{24}$ En primer plano se dibuja el molino de San Antonio y atrás los de Enmedio, Pápalo Tierno y de la Albolafia. Gámiz Gordo y Anguís Climent, 2005: 80-89.

${ }^{25}$ Otras vistas de Vivian (1838) o Guesdon (1853-55) incluían palmeras, un árbol característico de Córdoba que ya aparece en la vista más antigua de Córdoba, el sello del concejo de 1364. Caro Baroja, 1958: 197.

26 "Castillo de la Kalaorra”, 1833 (lápiz y acuarela) subastado en Christie's (18-9-1996, lote 200); "Moorish tower on the bridge at Cordova" (óleo s. lienzo) subastado en Sotheby's (29-10-1992, lote 13).

Arch. esp. arte, LXXXVIII, 352, oCTUBRE-DICIEMBRE 2015, 367-386

ISSN: 0004-0428, eISSN: 1988-8511, doi: 10.3989/aearte.2015.23 


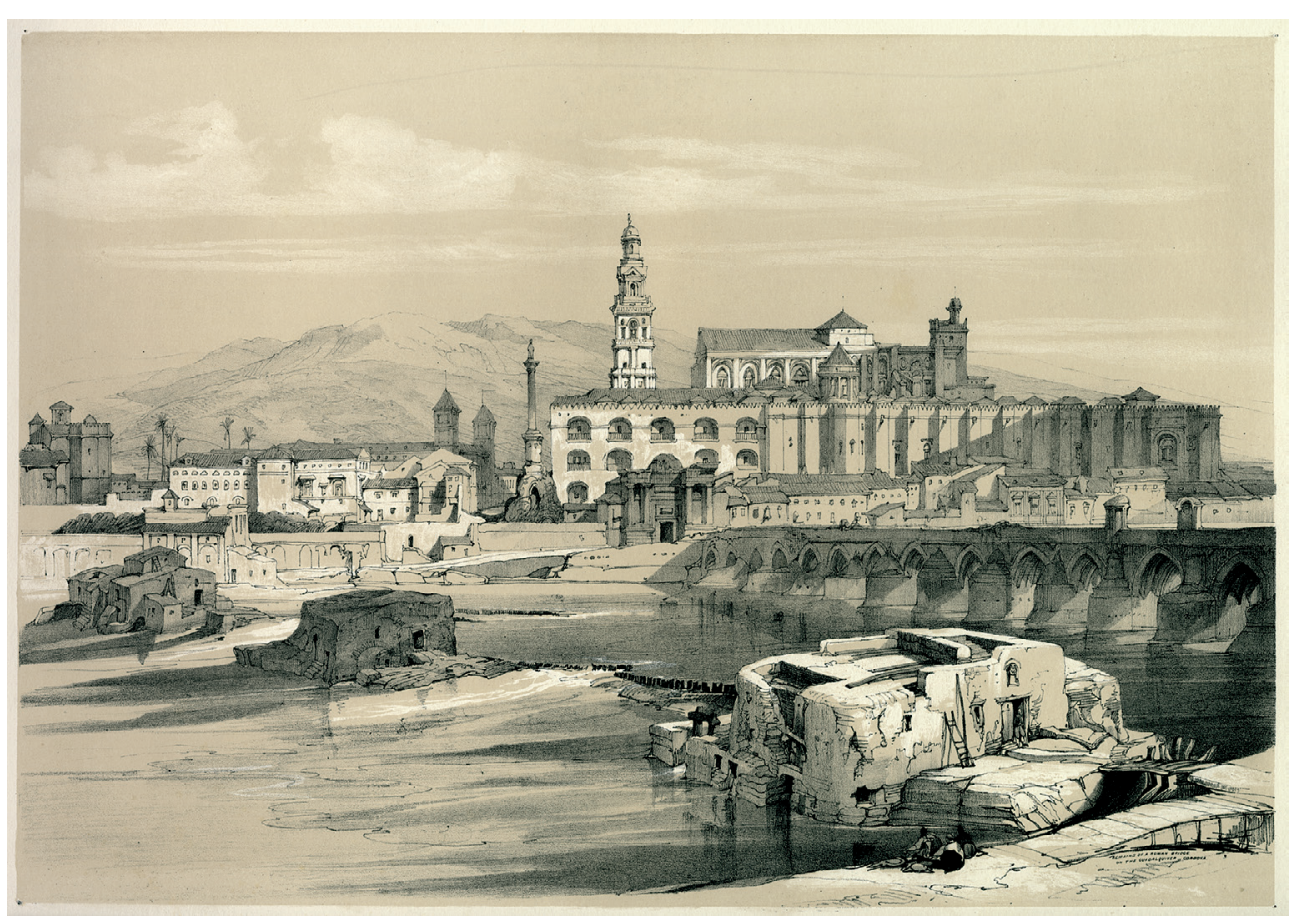

Fig. 1. D. Roberts (T.S. Boys, lit.): Great Mosque and Palace of the Archbishop, Cordova, 1837 (plate XXIV). Col. Particular.

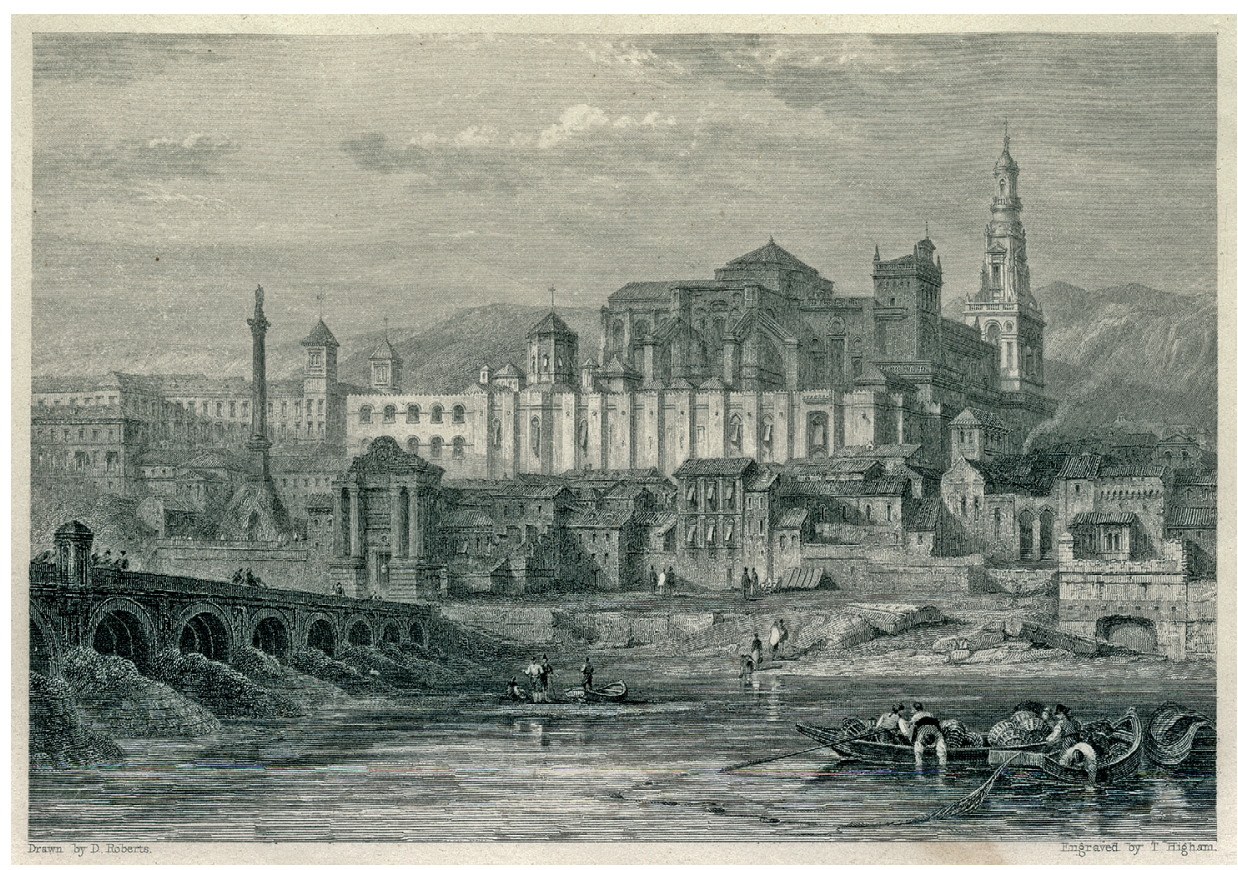

Fig. 2. D. Roberts (T. Higham, grab.): The Great Mosque \& the Alcazar, or Dungeon of the Inquisition, Cordova, on the Guadalquiver, 1845. Col. Particular.

Arch. esp. arte, LXXXVIII, 352, OCTUBRE-DICIEMBRE 2015, 367-386 ISSN: 0004-0428, eISSN: 1988-8511, doi: 10.3989/aearte.2015.23 


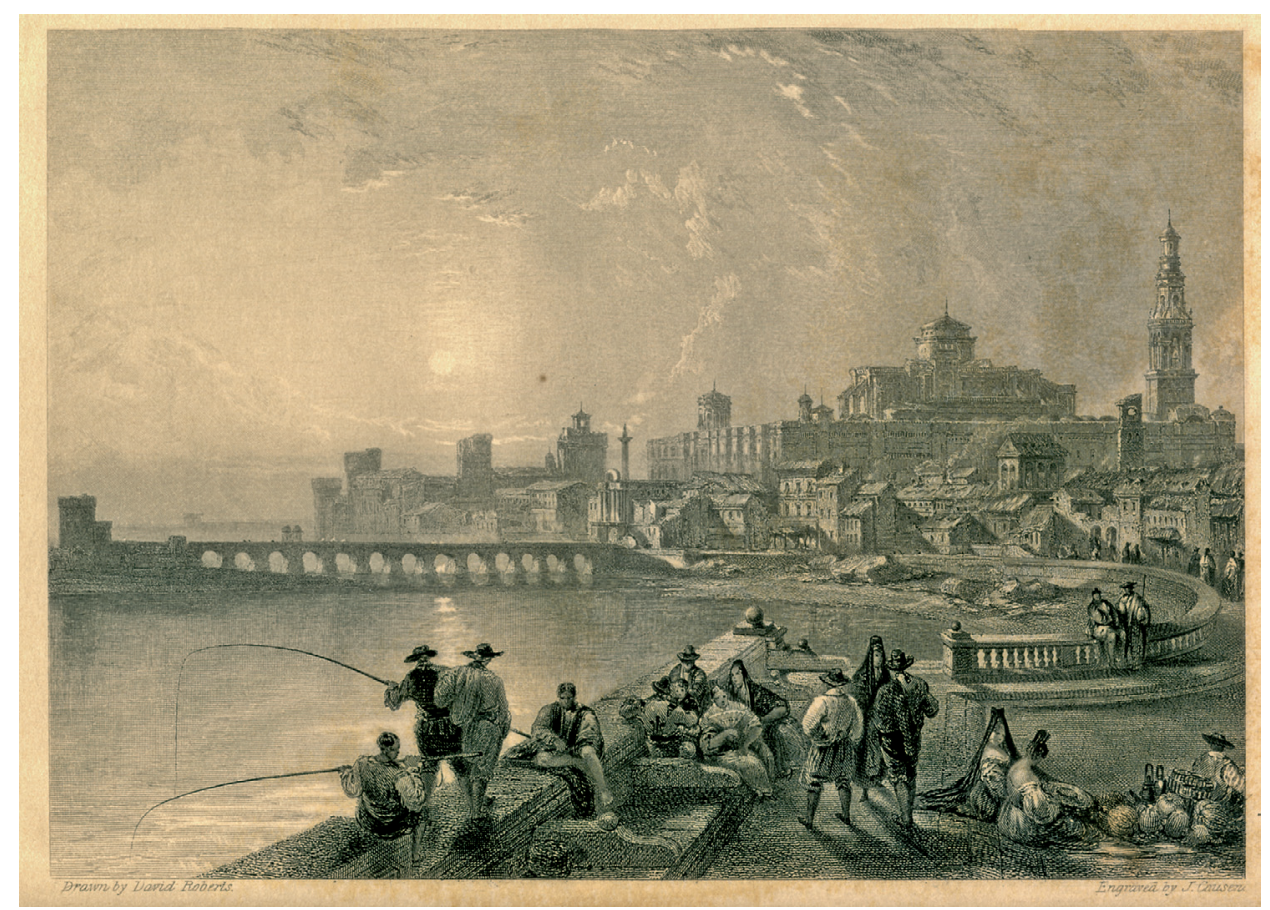

Fig. 3. D. Roberts (J. Causen, grab.): Cordova, looking down the Guadalquivir, 1836. Col. particular.

Otro grabado de Roberts tomado desde un punto de vista hacia el oeste, cerca del meandro del río ${ }^{27}$ se titula "Cordova. Looking down the Guadelquiver" (engraved by J. Causen) 1836 (fig. 3). Allí se empezó a construir en la primera mitad del siglo XIX un muro de defensa, cuya coronación aparece en primer plano. El tramo hasta el puente aún no se había ejecutado, según ratifica la vista de Roberts, conservándose el borde natural de la ribera. El perfil urbano engloba la Calahorra, el puente y su puerta, el Alcázar, el Triunfo de San Rafael, y la Mezquita-Catedral, cuya torre-campanario está ahora mejor proporcionada, sobresaliendo tras las casas con fachada al río. En primer plano personajes con trajes típicos reflejan la vitalidad del lugar, donde se pescaba con caña, costumbre usual hasta hace pocos años ${ }^{28}$.

En el entorno del río, Roberts realizó un bello y poco conocido dibujo con acuarela y lápiz titulado "The Alcazar or Palace of the Moorish Kings at Cordova", "Jan 19 1833 ", hoy en el Dudley Museum and Art Gallery (fig. 4). Contradiciendo esta fecha abajo se añadió un rótulo erróneo, "David Roberts. 1832", además de imposible ya que no llegó a la ciudad hasta enero de 1833. Tampoco es exacto el título que atribuye el Alcázar a "the Moorish Kings", ya que el conjunto conservado era una obra sustancialmente cristiana ${ }^{29}$. Roberts tomaría esta vista desde el

${ }^{27}$ Desde el entorno de este lugar tomaron vistas Swinburne, 1779 y Chapuy, 1842-1844: $\mathrm{n}^{\circ} 52$.

${ }^{28}$ Existe una rara litografía francesa idéntica a este grabado, con la firma de Roberts, y con pequeños cambios en detalles o personajes, titulada "Cordova coté du Guadalquivir". Incluye las inscripciones "peint par David Robert; Lith. Par Bachmann; Lith. De Thierry fréres. Chez Wild, 38, pasaje du Saumon".

${ }^{29}$ Es fundación del rey castellano Alfonso XI (1328) ocupando parte del antiguo alcázar y palacio islámico, reedificándolo. Nieto Cumplido, 1980: 18.

Arch. esp. arte, LXXXVIII, 352, oCTUBRE-DICIEMBRE 2015, 367-386 ISSN: 0004-0428, eISSN: 1988-8511, doi: 10.3989/aearte.2015.23 
tramo central del puente, tratando con habilidad los distintos planos para dar profundidad al conjunto. Para ambientar el lugar sitúa personajes en la azotea del cercano molino llamado de Pápalo Tierno, al que se accedía por la azuda que lo unía con el molino de la Albolafia, en segundo plano. Dicha construcción, de origen islámico, incorporaba una gran rueda de noria para suministrar agua al Alcázar y palacio islámico situado en sus inmediaciones, y su forma actual responde principalmente a la reedificación cristiana de los siglos XIV y XV; en este sentido, el dibujo de Roberts refleja con detalle las huellas de sucesivas transformaciones. A lo lejos se dibuja con precisión el Alcázar y sus distintas torres, de cuyo sector meridional quedan escasos restos, por lo que la imagen tiene gran valor documental: hoy, por ejemplo, no existen los altos edificios adosados, ni lo que parece ser una zona porticada, presidida por una estatua sobre una columna. Todo parece bastante fiel y concuerda con los planos de la ciudad de Karwinski (1811) y Montis (1851).

Otro grabado del mismo entorno incluye el título "Alcazar, or prison of the Inquisition, Cordova" (engraved by J. C.) 1836 (fig. 5). Se basa en un dibujo muy similar conservado en la Whitworth Art Gallery of the University of Manchester, y muestra el Alcázar cristiano, que hasta principios del siglo XIX alojaba el Tribunal de la Santa Inquisición ${ }^{30}$. La imagen se capta con un punto de vista cercano al anterior, pero ahora a nivel del río. Ambas vistas transmiten una sensación diferente del lugar: frente al sosiego de la primera, ésta adquiere más dramatismo, acentuado por los contrastes de luces, evocando un paraje donde se ajusticiaban los condenados a muerte, a la vista del pueblo; el edificio parece conservar su terrible destino. El molino de la Albolafia se dibuja con similar fidelidad, enfatizando su abandono y desperfectos, rodeado de escenas cotidianas: vacas paciendo en el río, personajes y pescadores que preparan su barca y enseres para sus tareas. $\mathrm{Y}$ al fondo, unas palmeras dan profundidad a la composición.

Otro dibujo tomado del natural de Roberts, con lápiz y acuarela, que incluye el título "Remains of a Roman Bridge at CORDOVA Jan $16^{\text {th }} 1833^{\text {", }}$, se encuentra hoy en una colección particular (fig. 6). En primer plano aparece el degradado edificio de la Albolafia, con sus dos grandes cuerpos de sillería, unidos por un acueducto, de los cuales el más cercano a la orilla fue demolido en el siglo XX al ampliarse el paseo del río. Posteriormente el arquitecto y arqueólogo Félix Hernández reconstruyó la gran rueda vertical hoy existente, basándose en elementos análogos cono$\operatorname{cidos}^{31}$. En segundo plano se dibujan fielmente el puente Romano y la puerta del Puente, con edificaciones adosadas, y al fondo asoman los muros de la Mezquita-Catedral, además de una curiosa espadaña, destacada en otra litografía del autor. A lo lejos se aprecia el hastial de la fachada principal de la iglesia de San Nicolás de la Ajerquía, hoy desaparecida. Estos planos sucesivos se plasman con fidelidad, aportando nuevamente gran profundidad a la vista.

El dibujo anterior serviría como base para ejecutar la litografía titulada "Mill and Bridge on the Guadalquivir, Cordova" (T. S. Cooper, lit.; pl. XXII) 1837 (fig. 7). En el ángulo inferior izquierdo aparece por error la fecha de 1832. Con intenciones didácticas y para explicar mejor el funcionamiento del antiguo molino que allí existiría, Roberts incorpora una pequeña rueda vertical, y una discutible construcción a modo de palafito. Dichos añadidos no aparecen en su dibujo previo, ni en otras vistas de Taylor o Vivian, ni tampoco en una posterior fotografía de Laurent (h. 1867) ${ }^{32}$. Atrás se dibuja la Mezquita-Catedral, el puente Romano y su puerta renacentista, a la que se adosa un edificio con arcos y pilastras ficticios, más una extraña chimenea en su cuerpo superior.

\footnotetext{
${ }^{30}$ La Inquisición se abolió en las Cortes de Cádiz de 1812. El plano de la ciudad de Karwinski (1811) rotula el lugar como "Inquisición”, y el de Montis (1851) ya como "cárcel”, un uso prolongado hasta mediados del siglo XX.

${ }^{31}$ Hernández Jiménez, 1962.

${ }^{32}$ Gámiz Gordo y Anguís Climent, 2005: 80-89.
}

Arch. esp. arte, LXXXVIII, 352, oCTUBRE-DICIEMBRE 2015, 367-386 ISSN: 0004-0428, eISSN: 1988-8511, doi: 10.3989/aearte.2015.23 


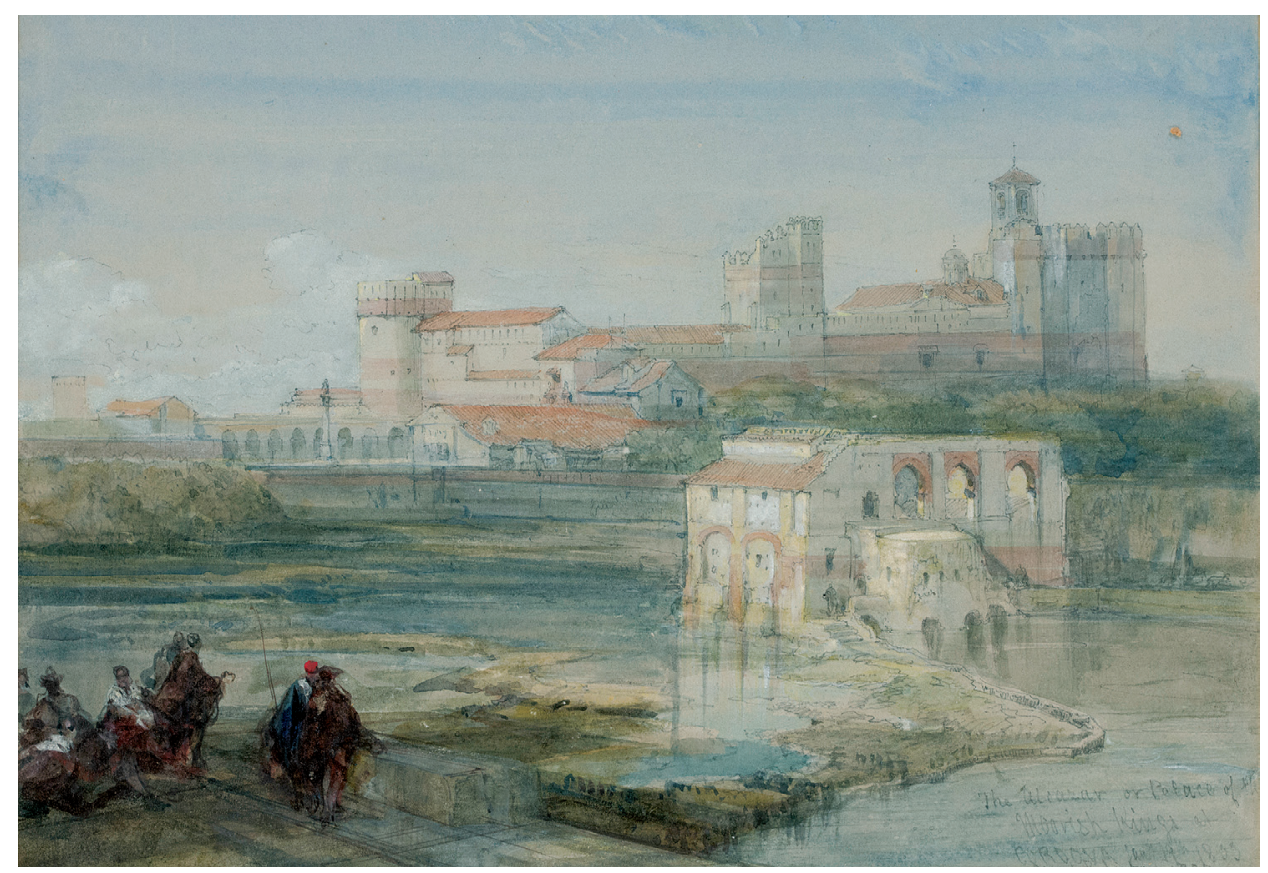

Fig. 4. D. Roberts: The Alcazar or Palace of Moorish Kings at Cordova, Jan. $19^{\text {th }} 1833$ (lápiz y acuarela). Dudley Museum and Art Gallery.

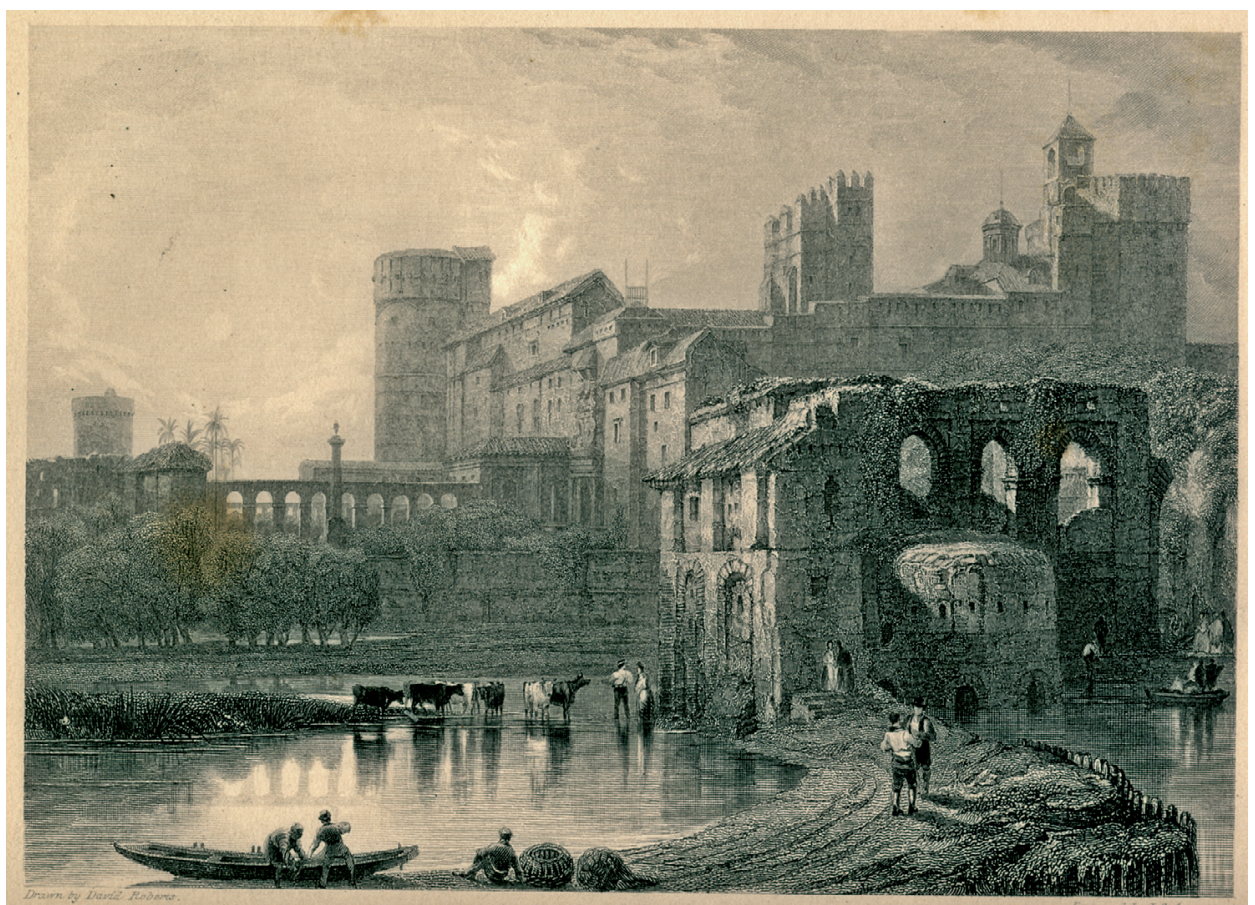

Fig. 5. D. Roberts (J.C. Armytage, grab.): Alcazar, or prison of the Inquisition, Cordova, 1836. Col. particular.

Arch. esp. arte, LXXXVIII, 352, OCTUBRE-DICIEMBRE 2015, 367-386 ISSN: 0004-0428, eISSN: 1988-8511, doi: 10.3989/aearte.2015.23 


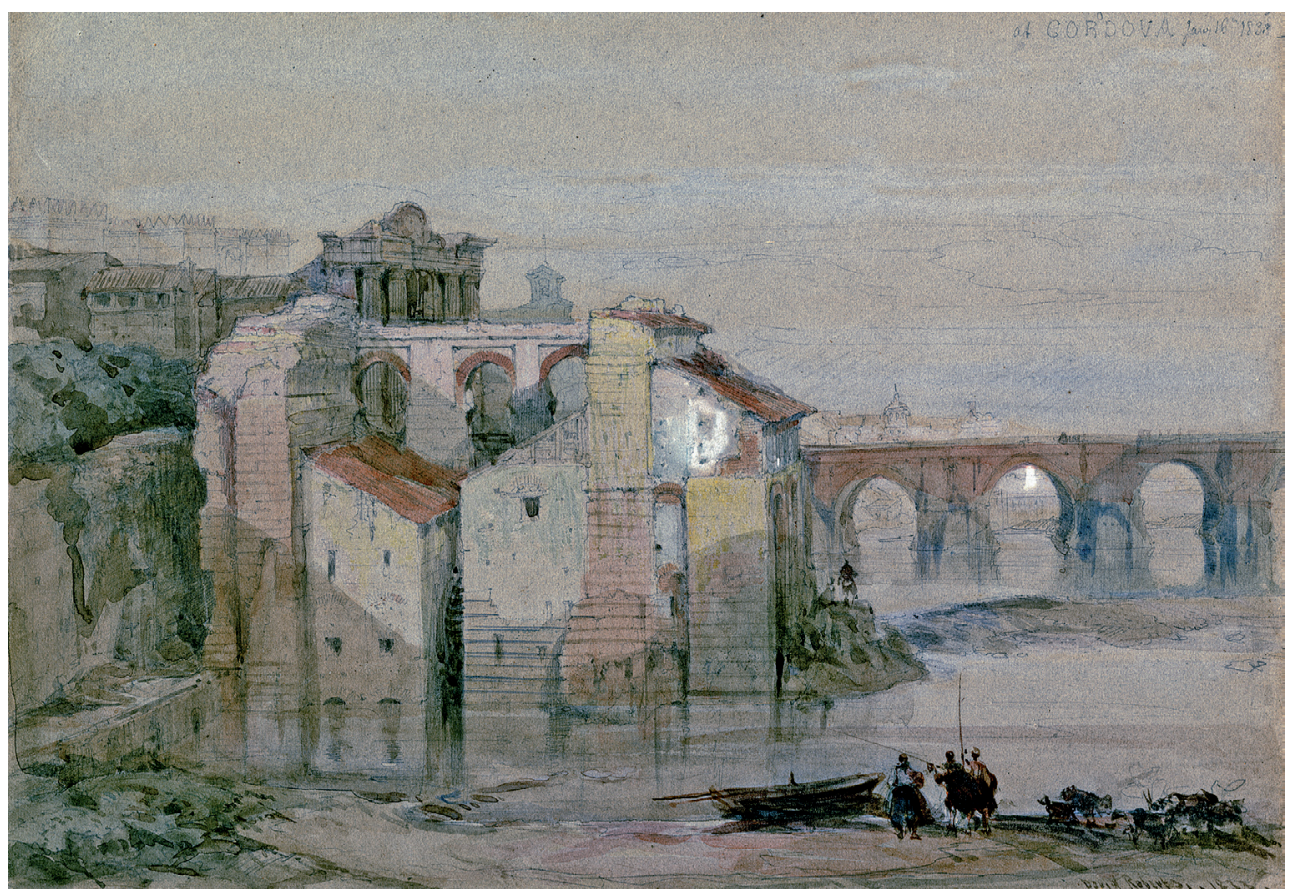

Fig. 6. D. Roberts: Remains of a Roman Bridge at Cordova, Jan $16^{\text {th }} 1833$ (lápiz y acuarela). Col. particular.

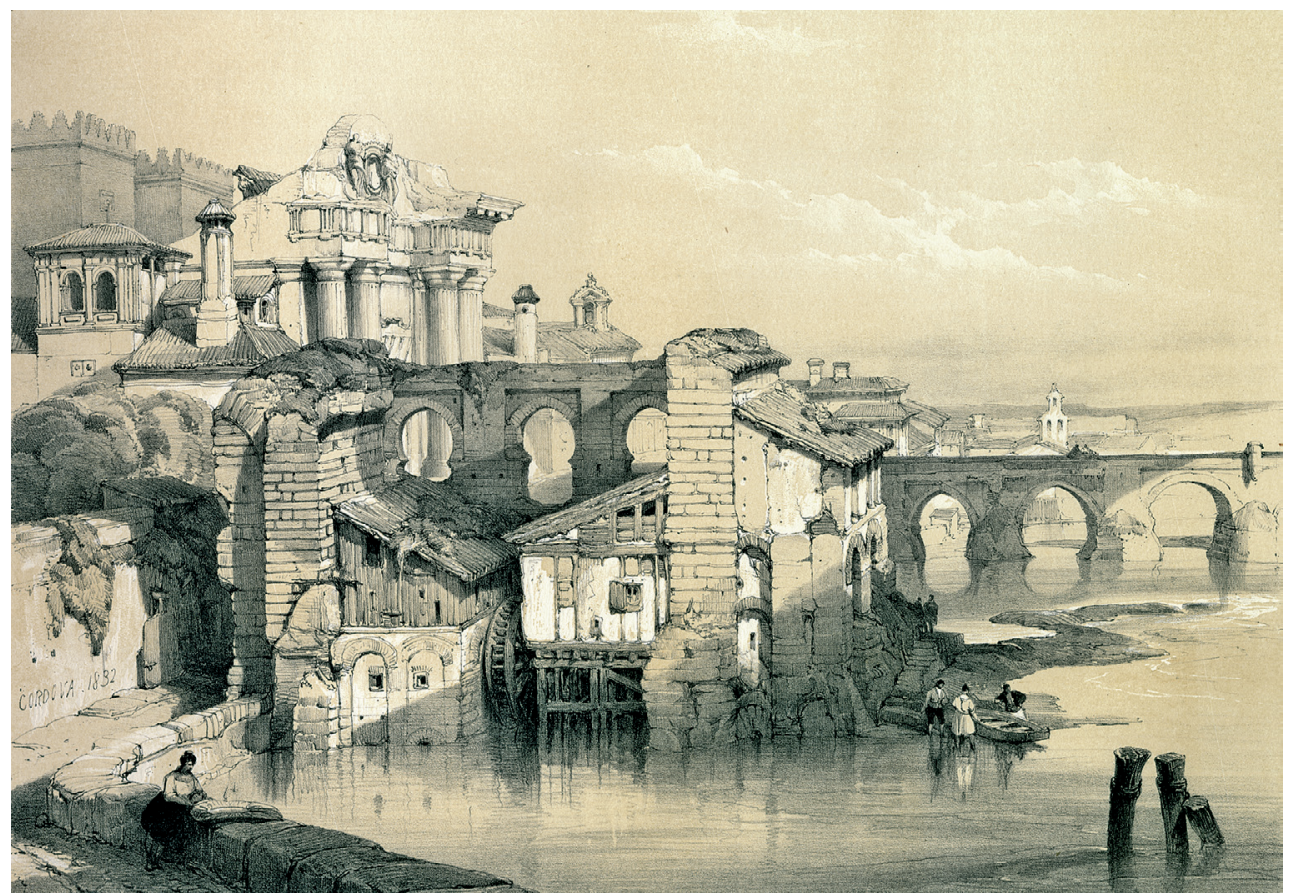

Fig. 7. D. Roberts (T.S. Cooper, lit.): Mill and Bridge on the Guadalquivir, Cordova, 1837 (plate XXII). Col. Particular.

Arch. esp. arte, LXXXVIII, 352, oCTUBRE-DICIEMBRE 2015, 367-386 ISSN: 0004-0428, eISSN: 1988-8511, doi: 10.3989/aearte.2015.23 


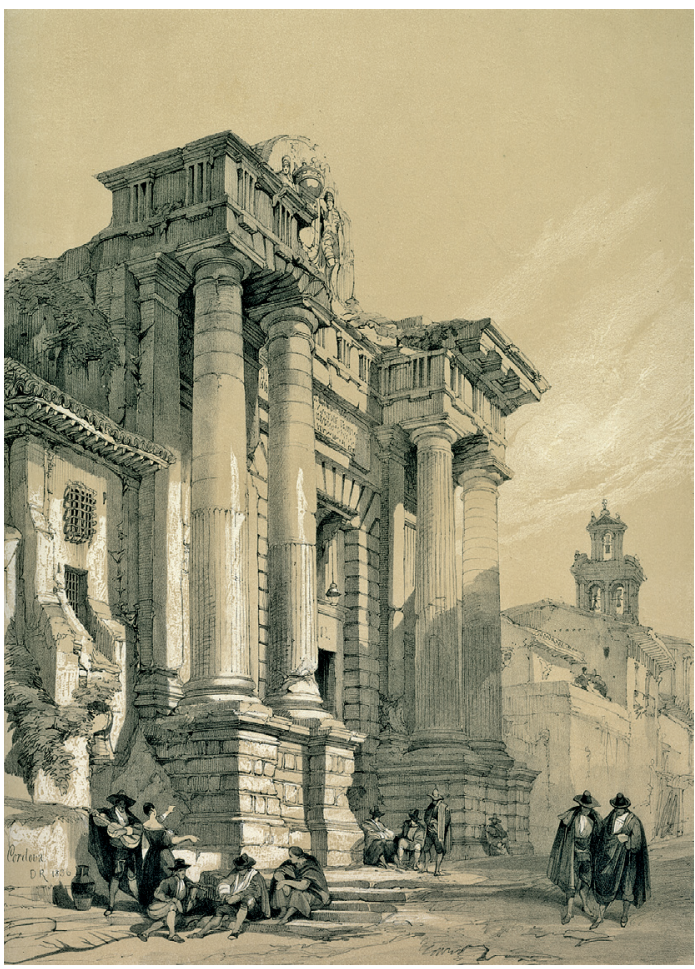

Fig. 8. D. Roberts (T.S. Boys, lit.): Antient Roman Gateway, Cordova, 1837 (plate XII). Col. particular.

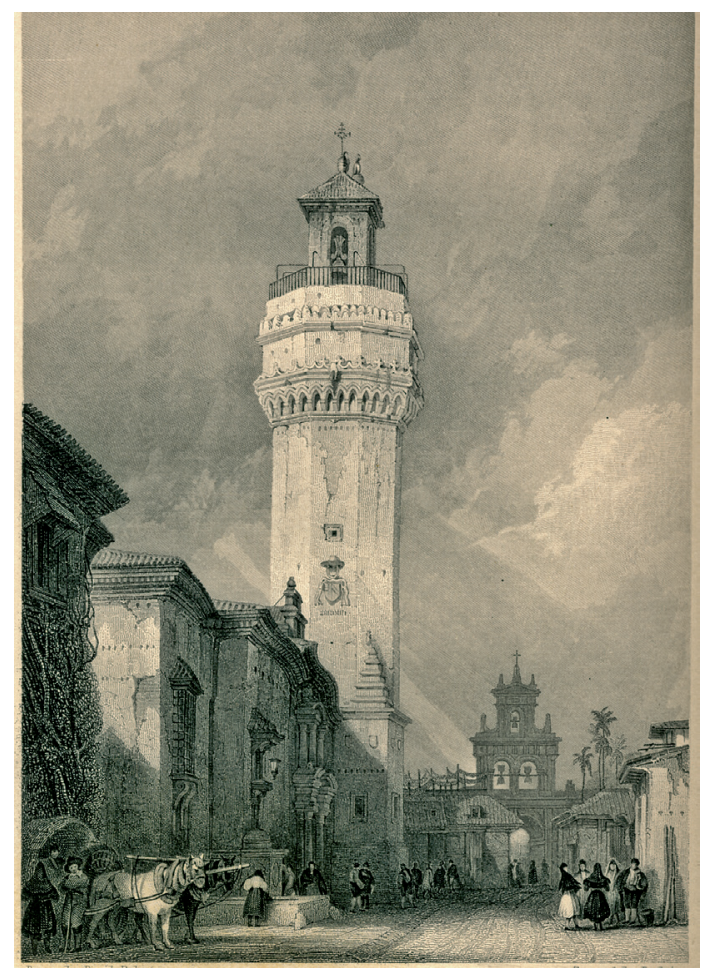

Fig. 9. D. Roberts (Freebairn, grab.): Tower of the church of San Nicolas, Cordova, 1836. Col. particular.

Una bella litografía titulada “Antient Roman Gateway, Cordova” (T. S. Boys, lit.; pl. XII) 1837 (fig. 8) muestra una fiel perspectiva de la puerta del Puente, una de las más simbólicas de la ciudad desde tiempos islámicos, cuya primitiva conformación islámica se apreciaba en la vista de Anton van den Wyngaerde (1567). Fue transformada por Hernán Ruiz III, que añadió una portada clasicista hacia el año 1575. Se compone con orden toscano, con cuatro columnas exentas sobre pedestal, tres de ellas estriadas en su parte inferior y una en su totalidad, que Roberts plasmó con rigor. Sobre ellas se sitúa el entablamento, una potente cornisa inacabada, el frontón central en ruinas, y el pequeño retablo que allí existió. La casita adosada en primer plano sería la capilla de los Ahogados, hoy desaparecida, y la espadaña que asoma detrás, muy ornamentada, se realza más que en el dibujo antes citado. Además, un grupo de personajes animan el lugar, con una mujer bailando al compás de una guitarra española. El dibujo constituye un valioso testimonio sobre la conformación original de la puerta y su entorno urbano, hoy muy transformado, y parece bastante precisa si se compara con una vista de Parcerisa (1856) realizada con soporte fotográfico.

En el sector norte de la ciudad Roberts realizó la vista titulada "Tower of the church of San Nicolas, Cordova" (engraved by Freebairn) 1836 (fig. 9), dibujando una de las torres más conocidas de las parroquias bajomedievales cordobesas, concluida en 1496, cuya volumetría está bien plasmada, aunque con las cornisas algo exageradas. Junto a la torre aparece una portada renacentista que diseñó Hernán Ruiz el joven, también sobredimensionada en su cuerpo superior. Aunque Roberts dibuja con cierto rigor, es una incógnita la existencia de los dos altares representados, que no aparecen en otra vista anterior de Taylor. Además, al fondo aparece la puerta de muralla conocida

Arch. esp. arte, LXXXVIII, 352, oCTUBRE-DICIEMBRE 2015, 367-386 ISSN: 0004-0428, eISSN: 1988-8511, doi: 10.3989/aearte.2015.23 


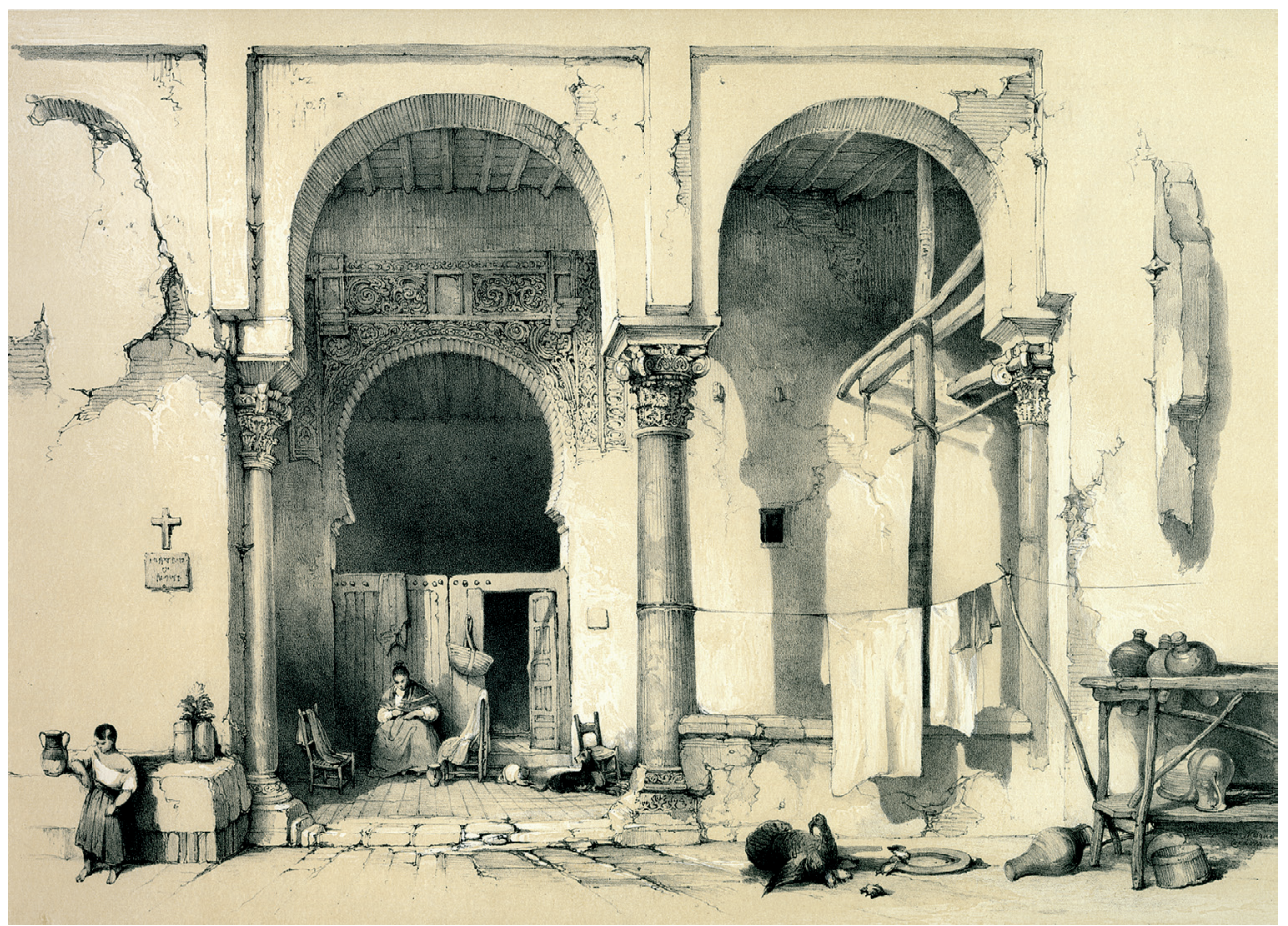

Fig. 10. D. Roberts (W. Gauci, lit.): Porch of an Antient Mosque, Cordova, 1837 (plate XXI). Col. particular.

como de los Gallegos, no visible desde dicho punto de vista, y cuya representación tiene cierta lógica al constituir el final de un importante eje urbano este-oeste. Sin embargo parece poco probable la existencia de la espadaña dibujada, pues ésta no aparece en una foto de $1868^{33}$. La escena gana profundidad con unas palmeras tras la muralla, plantadas en lo que hoy siguen siendo jardines de la Victoria.

La acuarela previa a este grabado (1835), conservada en The Fitzwilliam Museum, es bastante similar a otro óleo (1834) localizado en The Hepworth Wakefield con la misma torre en su entorno urbano. En este último se eleva el punto de vista, se introducen nuevos personajes y se añaden elementos de arquitectura clásica, aunque no aparecen los dos altares citados.

Otra litografía de Roberts titulada "Porch of an Ancient Mosque, Cordova" (W. Gauci, lit.; pl. XXI) 1837 (fig. 10) se realizó a partir de un apunte al natural con similar título, fechado el 22 de enero ${ }^{34}$. En realidad el edificio no era una antigua mezquita, sino una casa palaciega mudéjar del siglo XV, hoy transformada y conocida como la casa de las Campanas. Cuando Roberts la visitó la habitaban gentes humildes, dibujadas junto con sus enseres. El pórtico, hoy muy reformado, tiene capiteles islámicos reaprovechados, y sus proporciones se realzan verticalmente, dis-

${ }^{33}$ Cosano Moyano, 1999: 126. Algo similar ocurre con una espadaña que aparece en otro importante óleo de Roberts sobre la Alhambra, vista desde el Albaicín, que se conserva en la colección Caja Granada.

${ }^{34}$ Guiterman y Llewellyn, 1986: 108, cat. 88. 
minuyéndose a la vez el tamaño de los personajes. El dibujo es fiel a la realidad y de gran valor para la futura recuperación de los arcos laterales, transformados en la segunda mitad del siglo XIX ${ }^{35}$. La portada, con ornamentación islámica que Roberts dibujó de forma simplificada, debido a su complejidad geométrica, está hoy flanqueada por dos huecos que no existían en 1833; su puerta daba acceso a una sala en penumbra, componiendo un esquema de organización habitual en la arquitectura doméstica islámica, con sala, pórtico y patio situados a eje $\mathrm{e}^{36}$.

\section{Recorrido por las vistas interiores de la Mezquita-Catedral}

El interior de la Mezquita-Catedral es un lugar mágico que despertaría la mayor atención de Roberts. Éste debió estudiar detalladamente el edificio, pues su carta cita las dimensiones en planta y el plano en el que contó sus columnas, hablando incluso de su ubicación en el solar de un templo romano ${ }^{37}$. El artista dedicó a sus interiores las vistas comentadas a continuación.

Entre sus originales tiene gran valor uno sin título ${ }^{38}$ sobre una capilla con un retablo barroco desmantelado en 1879, hoy en un convento cercano, y de la que apenas se conocen imágenes. Este espacio se formalizó bajo el lucernario de al-Hakam II (año 962), hoy conocido como capilla de Villaviciosa, y previamente fue el presbiterio de la primera iglesia allí construida en el año 1489, demoliéndose las arquerías de uno de los laterales ${ }^{39}$. En primer plano se aprecian los bellos arcos entrelazados islámicos, más unos escalones y una baranda que delimitan el interior sobreelevado, con el retablo y sus cuatro columnas salomónicas. Los arcos del primer plano no corresponden a la realidad: Roberts dibujó en el lugar de éstos los existentes en el lateral interior de la capilla.

Dicho original serviría como base de una litografía titulada "Chapel in the Great Mosque, Cordova" (T. S. Boys, lit.; pl. XIII) 1837 (fig. 11) que abajo a la izquierda incluye la inscripción "The Mosque. Cordova". En primer plano se plasman fielmente las columnas y bóvedas barrocas que hasta el siglo XX ocultaron la techumbre islámica. La luz ahora es más intensa, acentuándose las sombras, y se dibujan personajes reducidos en tamaño. En vez de gentes sencillas, ahora figuran clérigos y monaguillos. Roberts debió realizar varios dibujos para acometer una composición final tan sofisticada. En este sentido cabe recordar la existencia de una viñeta (1835) poco elaborada pero fiel, sobre la contigua Capilla Real, donde fueron enterrados los reyes castellanos Fernando IV y su hijo Alfonso XI.

Otro grabado, con una vista de la nave contigua a la anterior, mirando en dirección opuesta, se titula "Interior of the great Mosque at Cordova" (engraved by W. Wallis) 1836. La nave aparece con las bóvedas añadidas en los años 1713-23, y al fondo aparecen los arcos de la macsura, dibujada fielmente. Dichos arcos dejan entrever el muro de la Qibla, con el hueco que daba acceso al sabat, un ámbito de uso exclusivo del califa. Los capiteles no se dibujan con precisión y los personajes de menor tamaño alteran la escala del lugar. También la iluminación es irreal, pues la nave estaría en penumbra, en contraste con la luz cenital de la macsura. Sobre esta vista Roberts realizó una versión en óleo, "The Sanctuary of the Koran" (1849) localizado en Leicester Galleries, con leves diferencias: el punto de vista se desplaza a la derecha, en la misma nave, arcadas y

\footnotetext{
${ }^{35}$ Sobre este patio se ha localizado la foto de un cuadro firmado por Arturo Nogales (1899) y una postal datada hacia 1905; que incluyen la arquería con los arcos laterales del pórtico ya reformados.

${ }^{36}$ Este esquema arquitectónico tiene su origen en los palacios cordobeses de Madinat-alZahra (s. X) y se encuentra en toda la arquitectura de Al-Ándalus. Almagro Gorbea, 2008.

${ }^{37}$ Calvo Capilla, 2007: 143-179.

${ }^{38}$ Autores varios, 2005: 47-48.

${ }^{39}$ La capilla aparece en el primer plano de la Mezquita-Catedral (1741) y figura por última vez en plano de Velázquez Bosco (1891). Nieto Cumplido y Luca de Tena y Alvear, 1992: 12, 16, 21, 26.
}

Arch. esp. arte, LXXXVIII, 352, oCTUBRE-DICIEMBRE 2015, 367-386 ISSN: 0004-0428, eISSN: 1988-8511, doi: 10.3989/aearte.2015.23 


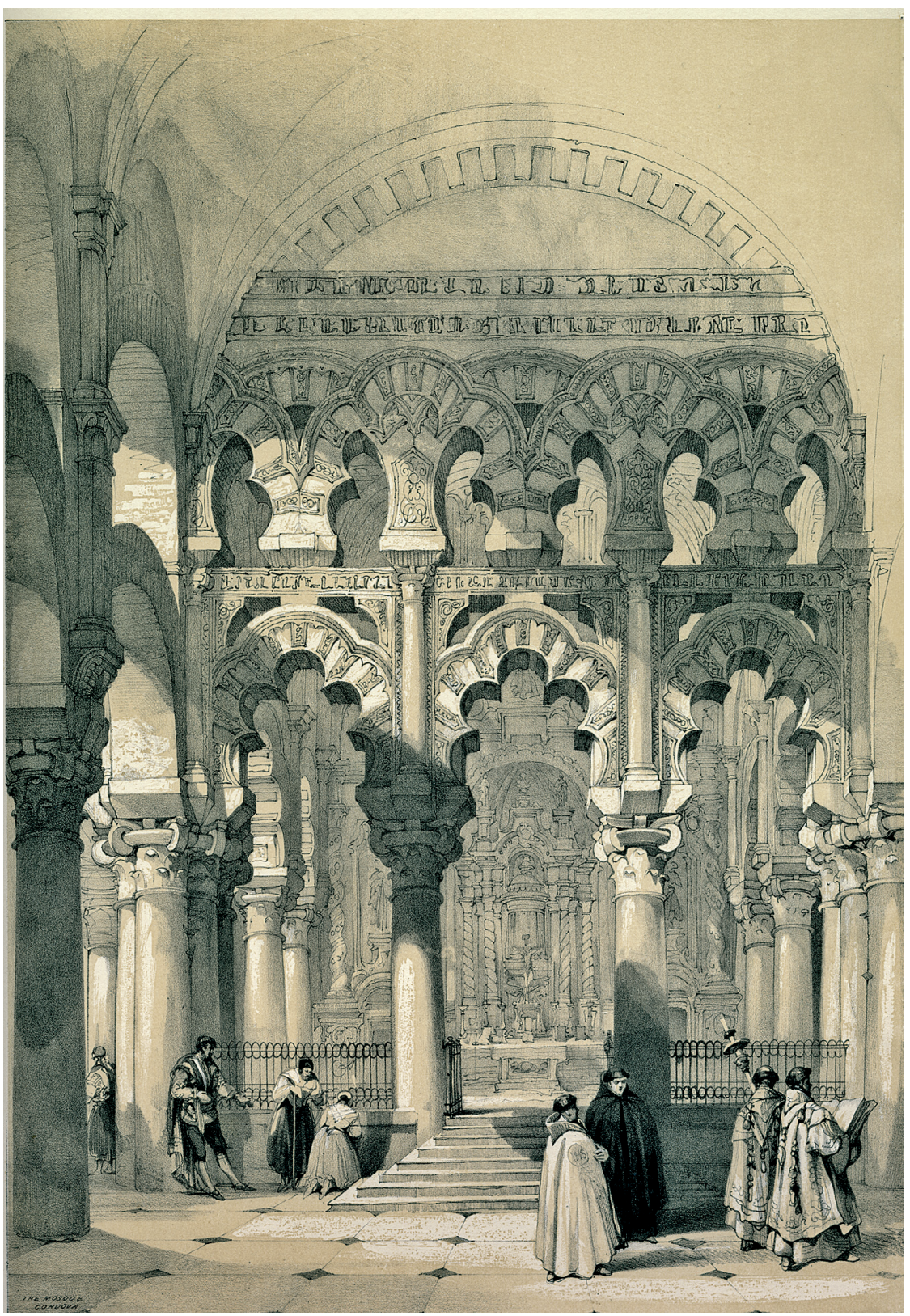

Fig. 11. D. Roberts

(T.S. Boys, lit.): Chapel in the Great Mosque, Cordova, 1837 (plate XIII). Col. particular.

bóvedas aparecen encaladas de blanco, y no se detalla el color alternante de las columnas. La intensa iluminación natural en la macsura sugiere un ambiente espacial muy distinto.

Finalmente cabe destacar un importante óleo (1838) hoy en el Museo del Prado de Madrid, con una vista de la nave del Mihrab de la Mezquita (fig. 12). La composición es muy fiel a la realidad de la macsura, salvo los escalones que sobreelevan dicho espacio, donde se sitúan distintos personajes y mujeres con trajes típicos. Estamos ante el lugar principal de la Mezquita, un espacio cargado de simbolismo, que Roberts plasma magistralmente con un rico cromatismo y una 


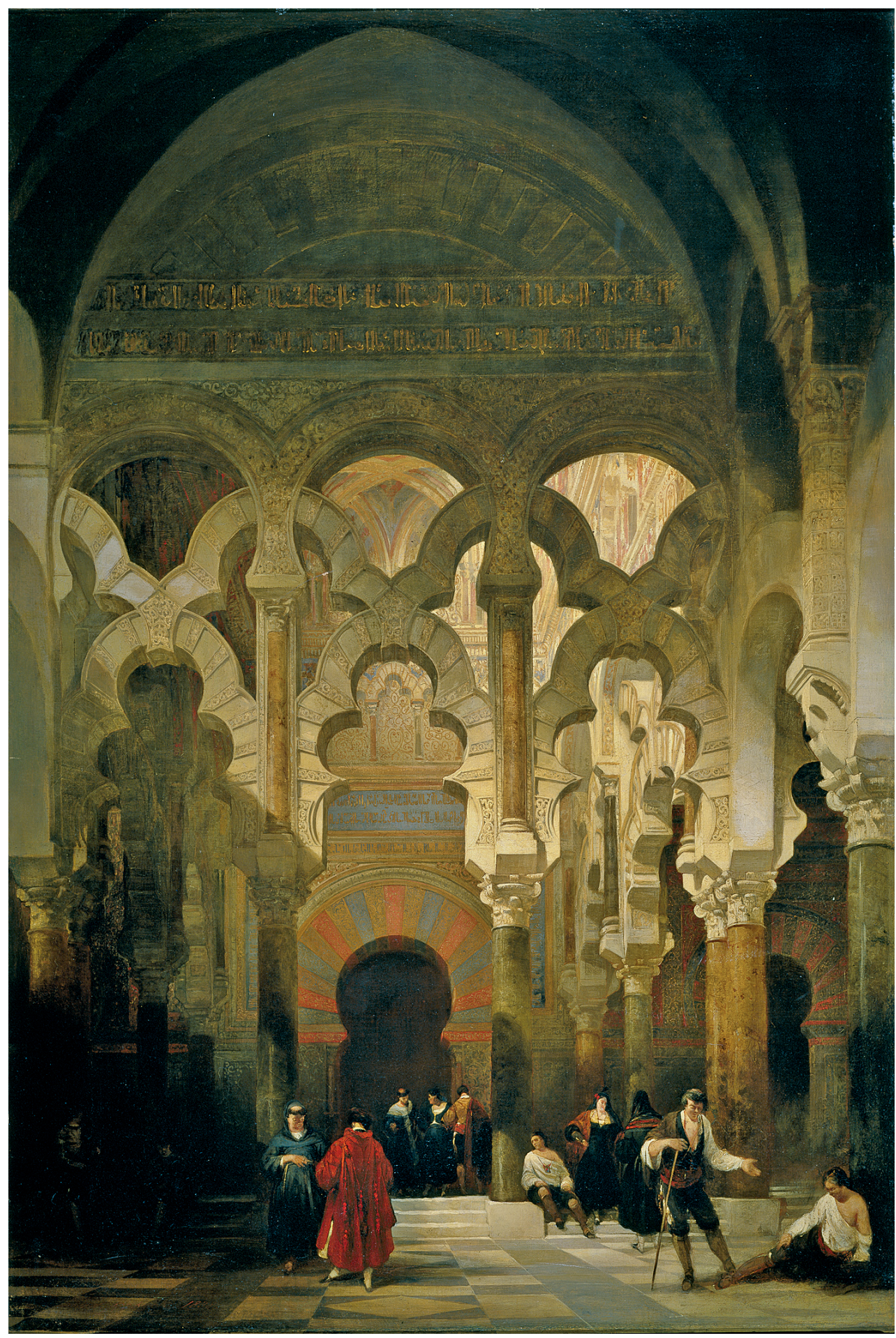

Fig. 12. D. Roberts: [Mihrab de la Mezquita de Córdoba] (óleo sobre lienzo) 1838. (C) Museo del Prado, Madrid.

Arch. esp. arte, LXXXVIII, 352, oCTUBRE-DICIEMBRE 2015, 367-386 ISSN: 0004-0428, eISSN: 1988-8511, doi: 10.3989/aearte.2015.23 
sugerente iluminación, detallando con prodigiosa calidad gráfica los paramentos y bóvedas, visibles a través de los arcos entrelazados. Éstos adquieren gran protagonismo en la composición, aunque se dibujan algo adelgazados, quizás para favorecer la transparencia de espacios. Estos ajustes serían intencionados, ya que el dibujo previo tomado del natural, titulado "Chapel of Mahomed in the Mosque at Cordoba" $(1833)^{40}$ muestra fielmente la arquitectura del lugar y la macsura sin los escalones citados. Otra acuarela ${ }^{41}$ que también detalla el Mihrab se publicó como viñeta en 1835.

\section{Conclusiones}

Al pasar por Córdoba, Roberts centró su interés en el espacio paisajístico y monumental situado junto al río Guadalquivir y en el interior de la Mezquita-Catedral. El pasado islámico de la ciudad le llamó especialmente la atención, al igual que a otros viajeros de aquel tiempo, dada la importancia de los elementos conservados en la antigua capital del Califato Omeya. Sin embargo, la obra de Roberts destaca entre otros artistas que dibujaron Córdoba en la primera mitad del siglo XIX (Laborde, Taylor, Vivian, Chapuy...) por el mayor número de sus imágenes, por la riqueza y variedad de sus puntos de vista y por su mayor precisión.

Las vistas de Roberts recogen con bastante fidelidad el paisaje y la arquitectura de Córdoba y son un testimonio de enorme valor para conocer lugares y edificios hoy perdidos o transformados. Debe destacarse la coherencia entre distintas imágenes de un mismo lugar, así como la concordancia con elementos que subsisten o con otros dibujos de la época. También resulta sobresaliente su capacidad para plasmar un mismo lugar con ambientaciones distintas, jugando con la iluminación, las profundidades o evocando el pasado. Su experiencia previa como escenógrafo resulta palpable en la maestría de sus composiciones, o en el manejo de la escala de los lugares dibujados. Además, al rehacer sus vistas a veces introducía variantes gráficas o añadía elementos puntuales, como espadañas, altares o molduras en edificios que no las tuvieron, tratando posiblemente de mejorar el interés de lo representado.

Esta práctica ha motivado que ciertos autores piensen que sus vistas son irreales y fantasiosas, considerándole como un inventor de paisajes. Sin embargo, en este artículo se evidencia que, en general, sus imágenes son bastante veraces, a pesar de sus manipulaciones, y que en todo caso deben analizarse cuidadosamente para su adecuada comprensión y valoración. Así, por ejemplo, en la Albolafia trataría de mostrar, de forma didáctica, su funcionamiento en otros tiempos, añadiendo -con razonable lógica constructiva- una rueda vertical y elementos de madera inexistentes en el boceto previo aquí aportado.

En definitiva, puede calificarse a David Roberts como un gran pintor de paisajes y arquitecturas, un hábil constructor gráfico con expresivos puntos de vista y sofisticados recursos en sus escenas, un verdadero paisajista. Frente a los argumentos sobre falta de objetividad o de verosimilitud que se le han achacado, el análisis de las vistas de Córdoba evidencia que en éstas predomina claramente lo real sobre lo fantástico, con las matizaciones expuestas. No deben olvidarse las palabras anotadas el 16 de marzo de 1833 en el diario de William Mark, cónsul inglés en Málaga y amigo personal de Roberts, que le acompañó en dicha ciudad: "El Sr. Roberts ha venido a España para hacer un estudio fiel y alejarse en su obra de lo meramente pintoresco y es, en este sentido, inigualable" ${ }^{, 42}$.

\footnotetext{
${ }^{40}$ Guiterman y Llewellyn, 1986: 60 y 108 (cat. 87).

${ }^{41}$ Subastada en Sotheby's, 10-4-1997, lote 166.

42 Giménez Cruz, 2002: 185-186.
} 
En efecto, en el caso de Córdoba estamos ante el más importante paisajista que dibujó su conjunto en el siglo XIX, cuando aún no existía la fotografía como registro documental. Su legado gráfico tiene, además de un gran interés artístico, un enorme valor para conocer mejor el patrimonio paisajístico y arquitectónico de una ciudad hoy considerada Patrimonio de la Humanidad.

\section{BIBLIOGRAFÍA}

Almagro Gorbea, Antonio (2008): Palacios Medievales Hispanos. Madrid: Real Academia de Bellas Artes de San Fernando.

Autores varios (2005): Artistas Románticos Británicos en Andalucía. Granada: Caja Granada, vol. 205.

Ballantine, James (1866): The life of David Roberts R. A. Edinburgo: Adam and Charles Black.

Calvo Serraller, Francisco (1995): La imagen romántica de España. Arte y Arquitectura del siglo XIX. Madrid: Alianza.

Calvo Capilla, Susana (2007): "Las primeras mezquitas de al-Andalus a través de las fuentes árabes“. En: Al-Qantara, vol. 28, pp. 143-179.

Caro Baroja, Julio (1958): "La ciudad de Córdoba desde la orilla izquierda del Guadalquivir, según un sello del siglo XIV". En: Al-Andalus XXIII, 1, p. 197.

Chapuy, Nicolás 1842-44): L'Espagne. Vues des principales villes de ce Royaume. Dessinees d'apres nature par Chapuy. París: Bulla.

Cosano Moyano, Francisco (1999): Iconografía de Córdoba. Siglos XIII-XIX. Córdoba: Cajasur.

Galera Andreu, Pedro (1992): La imagen romántica de la Alhambra. Madrid: El Viso.

Gámiz Gordo, Antonio (2010): "Las vistas de España del viajero David Roberts, pintor de paisajes y arquitecturas, h. 1833". En: EGA: revista de expresión gráfica arquitectónica, 15, pp. 54-65.

Gámiz Gordo, Antonio (2014): "Vistas de Carmona del XVI al XIX". En: Actas IX Congreso de Historia de Carmona, Universidad de Sevilla, pp. 245-268.

Gámiz Gordo, Antonio / Anguís Climent, Diego (2005): "Imágenes cordobesas: los Molinos y la Albolafia”. En: El Legado Andalusí, nº 22, pp. 80-89.

Gámiz Gordo, Antonio / García Ortega, Antonio Jesús (2012): "La primera colección de vistas de la Mezquita-Catedral de Córdoba en el Voyage de Laborde (1812)”. En: Archivo Español de Arte, vol. LXXXV, núm. 338, pp. 105-124.

Giménez Cruz, Antonio (2002): La España pintoresca de David Roberts. El viaje y los grabados del pintor. Málaga: Universidad de Málaga.

Guesdon, Alfred (h. 1853-55): L'Espagne a vol d'odiseau. París: Hauser y Delarue.

Guiterman, Helen / Llewellyn, Briony (1986): David Roberts. Londres: Phaidon Press y Barbican Art Gallery.

Hernández Jiménez, Félix (1962): "Restauración en el Molino de la Albolafia, en Córdoba”. En: Al-Mulk. Anuario de Estudios Arabistas, 2 (1961-62), pp. 161-174.

Inglis, Henry (1831): Spain in 1830, vol. II. Londres: Whittaker, Treacher and Co.

Laborde, Alexandre (1812): Voyage pittoresque et historique de l'Espagne, t. II. París: Pierre Didot l'Ainé.

Nieto Cumplido, Manuel (1980): Corpus Mediaevale Cordubense II (1256-1277). Córdoba: Monte de Piedad y Caja de Ahorros de Córdoba.

Nieto Cumplido, Manuel / Luca de Tena y Alvear, Carlos (1992): La Mezquita de Córdoba: planos y dibujos. Córdoba: Colegio Oficial de Arquitectos de Andalucía Occidental.

Roberts, David (1837): Picturesque sketches in Spain taken during the years 1832-1833. Londres: Hocgson and Graves.

Roberts, David / Roscoe, Thomas (1835-38): The tourist in Spain. Londres: R. Jennings, 4 vol.

Parcerisa, Francisco Javier / Madrazo, Pedro (1856): Recuerdos y bellezas de España, Córdoba. Madrid: Imprenta de D. José María Repullés.

Quesada, Luis (1996): Pintores españoles y extranjeros en Andalucía. Sevilla: Ed. Guadalquivir.

Sim, Katherine (1984): David Roberts R. A., 1796-1864. A Biography. Londres: Quartet Books.

Arch. esp. arte, LXXXVIII, 352, oCTUBRE-DICIEMBRE 2015, 367-386

ISSN: 0004-0428, eISSN: 1988-8511, doi: 10.3989/aearte.2015.23 
Swinburne, Henry (1779): Travels throught Spain in the years 1775 and 1776. Londres: P. Elmsly.

Taylor, Isidore Severin Justin (1860): Voyage Pittoresque en Espagne, en Portugal et sur de la côte d'Afrique, de Tanger à Tetouan. París: Gide fils, 3 vol., [1826].

Vivian, George (1838): Spanish Scenery. Londres: P. and D. Colnaghi.

Fecha de recepción: 08-V-2014

Fecha de aceptación: 10-X-2014

Arch. esp. arte, LXXXVIII, 352, oCTUBRE-DICIEMBRE 2015, 367-386 ISSN: 0004-0428, eISSN: 1988-8511, doi: 10.3989/aearte.2015.23 